\title{
Sensitivity of total protein creatinine ratio in urine for diagnosis diabetic nephropathy
}

\author{
Fatrinawati, Windarwati, Osman Sianipar* \\ Department of Clinical Pathology and Laboratory Medicine, Faculty of Medicine Universitas \\ Gadjah Mada/Dr Sardjito General Hospital, Yogyakarta, Indonesia
}

\begin{abstract}
Diabetic nephropathy is one of diabetic complications characterized by proteinuria and impaired renal function. Confirmation of diagnosis based either on urine value of albumin excretion rate (AER) $30-300 \mathrm{mg} / 24$ hours or albumin creatinine ratio (ACR) $30-300$ $\mathrm{mg} / \mathrm{g}$ or total protein creatinine ratio (TPCR) $150-500 \mathrm{mg} / \mathrm{g}$. It is reported that TPCR measurement is more acceptable since it is convenient, fast and does not require special preparation. The aim of this study was to investigate the accuracy of TPCR for diagnosis of diabetic nephropathy among patients with type 2 diabetes (type $2 \mathrm{DM}$ ). A diagnostic test study was conducted which involved 86 patients with type 2 DM where urine TPCR value equal or more than $150 \mathrm{mg} / \mathrm{g}$ was independently and blindly compared with AER as a refference standard to diagnose diabetic nephopathy. The inclusion criteria were patients with type 2 DM who suspected suffer from diabetic nephropathy (suffer from DM more than 4 years) and agree to participate in this study. Those whom were suffer from at least on of the following diseases urinary tract infection, congestive heart failure, liver dysfunction, pregnancy, multiple myeloma, microangiopathy hemolytic anemia (MAHA) and incomplete data were excluded from the study. Contingency $(2 \times 2)$ table analysis was used to calculate sensitivity, specificity, positive predictive value (PPV), negative predictive value (NPV), likelihood ratio for positive test result/LR( + ), likelihood ratio for negative test result/ LR(-), and accuracy. The average of TPCR among diabetic nephropathy patient was $248.07 \mathrm{mg} / \mathrm{g}$. It was significantly higher than compared to those non diabetic nephropathy patient $(103.52 \mathrm{mg} / \mathrm{g})$. It was found 75 true positive, 9 true negative, and 2 false positive. The result showed that TPCR had a sensitivity, specificity, PPV, and NPV of $97.4 \%, 100 \%, 100 \%$, and $81,8 \%$ respectively to diagnose diabetic nephropathy. The TPCR with value equal or more than $150 \mathrm{mg} / \mathrm{g}$ in the morning sample urine can be used to diagnose diabetic nephropathy.
\end{abstract}

\section{ABSTRAK}

Nefropati diabetik merupakan salah satu komplikasi diabetes yang ditandai dengan adanya proteinuria dan gangguan fungsi ginjal. Konfirmasi diagnosis didasarkan pada laju ekskresi albumin (AER) 30-300 mg/24 jam atau rasio kreatinin albumin (ACR) $30-300 \mathrm{mg} / \mathrm{g}$ atau rasio kreatinin protein total (TPCR) $150-500 \mathrm{mg} / \mathrm{g}$. Pengukuran TPCR lebih dapat diterima karena lebih mudah, cepat dan tidak memerlukan persiapan khusus. Penelitian ini bertujuan untuk mengkaji akurasi TPCR sebagai penentu diagnosis nefropati diabetik pada pasien dengan diabetes melitus tipe 2 (DM tipe2). Studi ini merupakan studi tes diagnostik dengan melibatkan 86 pasien DM tipe 2 dengan kadar TPCR urin sama atau lebih dari $150 \mathrm{mg} / \mathrm{g}$ yang secara independen atau buta (blindly) dibanding dengan AER sebagai rujukan standar untuk diagnosis nefropati diabetik. Kriteria inklusi adalah pasien DM tipe 2 yang diduga mengidap nefropati diabetik (menderita DM lebih dari 4 tahun) dan setuju untuk berpartisipasi dalam penelitian ini. Pasien yang setidaknya memiliki penyakit seperti

$\overline{\text { Corresponding author: osmansianipar@ugm.ac.id }}$ 
infeksi saluran kencing, gagal jantung kongesti, disfungsi hati, hamil, myeloma multipel, microangyopathy anemia hemolitik (MAHA) dan data yang tidak lengkap tidak termasuk dalam kriteria eksklusi. Analisis tabel kontingensi $(2 \times 2)$ digunakan untuk menghitung sensitifitas, spesifisitas, nilai prediktif positif (NPP), nilai prediktif negatif (NPN), rasio kemungkinan positif (RK + ), rasio kemungkinan negatif (RK-), dan akurasi. Rerata TPCR di antara pasien nefropati diabetik sebesar $248,07 \mathrm{mg} / \mathrm{g}$ dan lebih tinggi secara bermakna dibanding pasien yang tidak menderita nefropati diabetik $(103,52 \mathrm{mg} / \mathrm{g})$, serta ditemukan 75 positif benar, 9 negatif benar, dan 2 positif palsu. Hasil pemeriksaan menunjukkan bahwa TPCR memiliki sensitifitas $97,4 \%$, spesifisitas $100 \%$, NPP 100\%, dan NPN $81,8 \%$ untuk diagnosis nefropati diagnostik. TPCR dengan nilai sama atau lebih dari $150 \mathrm{mg} / \mathrm{g}$ pada sampel urin pagi dapat digunakan untuk diagnosis nefropati diabetik.

Keywords: diabetic nephropathy - total protein creatinine ratio - sensitivity - albumin excretion rate - diagnostic test study

\section{INTRODUCTION}

Diabetes mellitus (DM) is a group of metabolic diseases characterized by hyperglycemia due to defects in insulin secretion, insulin action, or both. Diabetes mellitus is a global health problem since its incidence is rising consistently for all age-groups worldwide. ${ }^{1,2}$ In 2014, WHO estimated that 422 million adults aged over 18 years in the world were living with DM. The prevalence of DM in South East Asia region increased from 17 million (4.1\%) in 1980 to 96 million (8.6\%) in $2014 .{ }^{1}$ Globally, the prevalence of DM was estimated to be $2.8 \%$ in 2000 and $4.4 \%$ in 2030 . The total number of people with DM worldwide is projected to rise from 171 million in 2000 to 366 million in $2030{ }^{2}$

Diabetic nephropathy is a common complication in patients with DM. It is the leading cause of chronic kidney disease in patients starting renal replacement therapy and associated with increased cardiovascular mortality. ${ }^{3}$ The prevalence of diabetic nephropathy is approximately 20 to $30 \%$ in type 2 DM during their lifetime. ${ }^{4}$ Progression of nephropathy was strongly associated with higher subsequent medical care costs in hypertensive patients with DM. Patients with normoalbuminuria who progressed to microalbuminuria experienced an annualized change in baseline costs that was USD 396 higher significantly than those who maintained normal albuminuria (USD 902 versus USD 506). In microalbuminuria group, progression was associated significantly with USD 747 difference in annualized change in outpatient costs compared with no progression (USD 1,056 versus USD 309). Its costs were $37 \%$ significantly higher following progression from normoalbuminuria to microalbuminuria (USD 10,188 vs. USD 7,424). ${ }^{5}$

Limited information on laboratory test to detect microalbuminuria might lead to an impact on delay in diagnosis of diabetic nephropathy. Microalbuminuria screening in patients with DM is required to detect the diabetic nephropathy as early as possible and to avoid end stage renal disease (ESRD). ${ }^{6}$ Common tests considered for chronic kidney disease (CKD) include urine albumin testing and creatinine-derived estimates of glomerular filtration rate (GFR). The tests can be conducted in order to slow the progression of kidney disease, to prevent ESRD and to reduce the risk of cardiovascuar disease. Moreover, in patients with type $2 \mathrm{DM}$, the 
tests are performed for the purposes of screening, diagnosis and monitoring response to treatment.

The CKD might be occured without increasing albuminuria in patients with type 2 DM. Therefore, both GFR and albuminuria testing are important tests in screening, diagnosis and monitoring of the patients. Albuminuria testing may be conducted by measurement of the albumin excretion rate (AER) or the albumin-creatinine ratio (ACR). ${ }^{7}$ however, random $\backslash$ nurine samples can be used. I nnMeasurement of urinary albumin can be influenced by a number of factors $\backslash$ nincluding: - urinary tract infection, $\backslash \backslash n$ high dietary protein intake, $\backslash \backslash n$ - congestive heart failure, $\mid \backslash n$ - acute febrile illness, $\backslash \backslash n$ menstruation or vaginal discharge, $\backslash \backslash n$ water loading, and $\backslash n$ - drugs (NSAIDS, ACEi Another albuminuria testing is total protein-creatinine ratio (TPCR) of random or spot urine sample. ${ }^{8-10}$ The measurement of TPCR on random ('spot') urine samples well correlates with 24 -h total protein and albumin excretion. It is reported that TPCR is more sensitive than ACR to predict clinically relevant proteinuria. It has sensitivity and specificity of $94 \%$ and $88 \%$ respectively at the threshold of $100 \mathrm{mg} / \mathrm{mmol} .^{9}$ The proteincreatinine ratio on a random urine sample provides evidence to "rule out" the presence of significant proteinuria as defined by a 24-h urine excretion measurement. ${ }^{10}$ The advantages of this examination using spot urine samples, making it more practical and shorter examination time. The examination is influenced by several factors such as infections, high-protein diet, pregnancy and physical activity, hepatic dysfunction and congestive heart failure. ${ }^{11}$

In Indonesia, especially in the Yogyakarta Special Region, the use of TPCR for the diagnosis of diabetic nephropathy in patients with type $2 \mathrm{DM}$ has not been routinely performed. Therefore, this study was conducted to evaluate the diagnostic performance of TPCR to detect the present of microalbuminuria in patients with type $2 \mathrm{DM}$.

\section{MATERIALS AND METHODS}

\section{Subjects}

The subjects selected with the inclusion criteria were patients with type 2 DM suspected diabetic nephropathy (DM over 4 years), and agreed to participate in this study. The subject who suffer either from urinary tract infection, or congestive heart failure, or hepatic dysfunction, or multiple myeloma, or microangiopathy hemolytic anemia (MAHA), or pregnancy, or incomplete data were excluded from the study.

\section{Procedure}

Laboratory tests were carried out for 2 days in Clinical Laboratory of Dr. Sardjito General Hospital, Yogyakarta. In the $1^{\text {st }}$ day, samples were taken for fasting blood glucose, 2 hours post prandial blood glucose, HbAlc, and spot urine. Fasting blood glucose tests, 2 hours post prandial blood glucose and HbAlc were measured from $2 \mathrm{~mL}$ of venous blood sample and the tests were conducted in the same day of sampling. Subjects on the $1^{\text {st }}$ day was also asked to collect $5 \mathrm{~mL}$ urine sample for urine albumin and creatinine measurements. Urine samples were then transferred into eppendorf tubes using a standardized micropipette, then labeled and kept at $-20^{\circ} \mathrm{C}$, pooled up to sufficient number of samples were accomplished. Subjects were also given written and oral instruction for 24 hours urine collection (when collection began, first urination was discarded then second and subsequent urination collected for 24 hours) into a 2,500 $\mathrm{mL}$ threaded cap bottle urine container. 
On the $2^{\text {nd }}$ day, 24 hours urine samples were collected. The collected 24-hour urine samples were homogenized by flipping the bottles as much as 5 times, after which the urine volume was recorded. Most homogeneous urine samples were transferred into eppendorf tubes using a standardized micropipette, then labeled and stored at $-20^{\circ} \mathrm{C}$, pooled until urine albumin tests performed after certain number of samples were collected. Fasting and 2 hours post prandial blood glucose level were measured according to hexokinase method. Hemoglobin A1c (HbA1c) was measured with chromatography method. Both urine albumin and total protein were measured using an immunoturbidimetric method. Urine creatinine was measured using Jaffe method.

Albumin excretion rate is urinary albumin excretion within 24 hours and measured using immunoturbidimetric method. The AER is the refference standard to assess microalbuminuria. In this study, diabetic nephropathy was defined by AER value of $\geq 30$ $\mathrm{mg} / 24$ hours. The TPCR manually calculated by dividing the total value of urine protein and urine creatinine, the results expressed in $\mathrm{mg} / \mathrm{g}$. In this study diagnosis diabetic nephropathy was established if TPCR value equal or more than $150 \mathrm{mg} / \mathrm{g} .^{8}$

\section{Data analysis}

Independent t-tests was used to test difference in mean age, fasting blood glucose, 2 hours post prandial blood glucose when data distribution was normal and the MannWhitney test if data distribution was not normal. Chi-Square test was applied to test the difference in proportions. The significance of the result set when $p$ value was less than 0.05 with a confidence interval of $95 \%$. Data were analyzed using 2 X 2 table and the results were expressed in sensitivity (Sn), specificity (Sp), accuracy, positive predictive value (PPV), negative predictive value (NPV), likelihood ratio positive and negative, and accuracy.

\section{Ethical consideration}

The protocol of the study was approved by the Medical and Health Research Ethics Committee, Faculty of Medicine, Universitas Gadjah Mada, Yogyakarta.

\section{RESULTS}

This study involved 86 patients with type $2 \mathrm{DM}$ that consisted of 40 males $(46.5 \%)$ and 46 females (53.5\%). Average age was 60.5 years, and there were 43 subject that less than 60 years old. Characteristics of the subjects completely could be seen in TABLE 1 .

TABLE 1. Characteristics of subjects

\begin{tabular}{lcc}
\hline \multicolumn{1}{c}{ Characteristics } & n & \% \\
\hline Gender & & \\
$\quad$ Male & 40 & 46.5 \\
$\quad$ Female & 46 & 53.5 \\
Age & & \\
$\quad \leq 60$ year & 43 & 50.0 \\
$\quad>60$ year & 43 & 50.0 \\
Education & & \\
$\quad$ Elementary School & 9 & 10.0 \\
$\quad$ Junior High School & 6 & 6.3 \\
$\quad$ Senior High School & 40 & 46.3 \\
$\quad$ College & 31 & 37.5 \\
Occupation & & \\
$\quad$ Household & 21 & 25.0 \\
Profesional & 3 & 2.5 \\
Government employees & 7 & 7.5 \\
Private employees & 3 & 2.5 \\
Entrepreneur & 7 & 7.5 \\
Others & 45 & 55.0 \\
\hline
\end{tabular}

Group of diabetic nephrophaty was not significantly different from non diabetic group according to body mass index, blood pressure, hypertension status, heart disease, 
dyslipidemia status, stroke, duration of DM, fasting blood glucose level, 2 hours post-prandial blood glucose level, mean of creatinine serum level as well as HbA1c level. Mean of TPCR level in diabetic nephropathy group was $248.07 \mathrm{mg} / \mathrm{g}$. It was significantly higher than non diabetic nephropathy group namely $103.52 \mathrm{mg} / \mathrm{g}$. In addition, mean of AER level in diabetic nephropath y group was $205.37 \mathrm{mg} / \mathrm{g}$ which also significantly higher than that in diabetic nephropathy group, 24.59 $\mathrm{mg} / \mathrm{g}$ (TABLE 2).

TABLE 2. Comparison of variables among diabetic nephropathy and non diabetic nephropathy

\begin{tabular}{|c|c|c|c|}
\hline Variable & DN $(n=77)$ & Non DN $(n=9)$ & $\mathbf{p}$ \\
\hline Body Mass Index (mean \pm SD) & $24.86 \pm 3.37$ & $25.24 \pm 2.81$ & 0.790 \\
\hline \multicolumn{4}{|l|}{ Hypertension [n (\%)] } \\
\hline Yes & $45(58.4)$ & $3(33.3)$ & \multirow{2}{*}{1.000} \\
\hline No & $32(41.6)$ & $6(66.7)$ & \\
\hline \multicolumn{4}{|l|}{ Heart disease $[\mathrm{n}(\%)]$} \\
\hline Yes & $26(33.8)$ & $3(33.3)$ & \multirow{2}{*}{0.384} \\
\hline No & $51(66.2)$ & $6(66.7)$ & \\
\hline \multicolumn{4}{|l|}{ Dislipidemia [n (\%)] } \\
\hline Yes & $50(64.9)$ & $5(55.6)$ & \multirow{2}{*}{0.659} \\
\hline No & $27(35.1)$ & $4(44.4)$ & \\
\hline \multicolumn{4}{|l|}{ Stroke $[\mathrm{n}(\%)]$} \\
\hline Yes & $7(9.1)$ & $2(22.2)$ & \multirow{2}{*}{0.133} \\
\hline No & $70(90.9)$ & $7(77.8)$ & \\
\hline Duration of DM (mean \pm SD years) & $9.95 \pm 7.56$ & $6.0 \pm 2.68$ & 0.168 \\
\hline \multicolumn{4}{|l|}{ Blood Pressure (mean $\pm \mathrm{SD} \mathrm{mmHg}$ ) } \\
\hline Systole & $126.12 \pm 11.67$ & $125.00 \pm 10.49$ & 0.824 \\
\hline Diastole & $77.69 \pm 7.17$ & $80.00 \pm 5.48$ & 0.450 \\
\hline Fasting Blood Glucose (mean \pm SD mg/dL) & $156.46 \pm 59.46$ & $139.83 \pm 17.95$ & 0.501 \\
\hline Blood Glucose 2HPP (mean \pm SD mg/dL) & $232.19 \pm 85.65$ & $195.17 \pm 52.09$ & 0.306 \\
\hline Serum creatinine $($ mean $\pm \mathrm{SD})$ & $1.10 \pm 0.23$ & $0.87 \pm 0.15$ & 0.630 \\
\hline HbA1c (mean \pm SD \%) & $7.97 \pm 2.21$ & $7.67 \pm 0.68$ & 0.891 \\
\hline TPCR (mean \pm SD mg/g) & $248.07 \pm 136.29$ & $103.52 \pm 35.07$ & 0.002 \\
\hline $\operatorname{AER}($ mean $\pm \mathrm{SD}$ mg/24 hours) & $205.37 \pm 134.32$ & $24.59 \pm 3.05$ & 0.000 \\
\hline
\end{tabular}

Note: $\mathrm{DN}=$ diabetic nephropathy; Non $\mathrm{DN}=$ non diabetic nephropathy

Less, equal or more than $150 \mathrm{mg} / \mathrm{g}$ comparison TPCR versus AER to detect diabetic nephropathy gave 75 true positive result and 9 true negative result. This comparison gave rise to two false positive result. Sensitivity and specificity of TPCR to diagnose diabetic nephropathy were respectively $97.4 \%$ and $100 \%$. TPCR had PPV of $100 \%$ and NPV $81.8 \%$. In overall TPCR had accuracy of $97.7 \%$ to diagnose diabetic nephropathy (TABLE 3). 
TABLE 3. Analysis of performance diagnosis TPCR with gold standard AER

\begin{tabular}{|l|c|c|}
\hline Performance of TPCR & Value & $95 \%$ CI \\
\hline Sensitivity (\%) & 97.4 & $93.3-100.0$ \\
Specificity (\%) & 100.0 & $95.0-100.0$ \\
Positive predictive value (\%) & 100.0 & $95.0-100.0$ \\
Negative predictive value (\%) & 81.8 & $65.0-89.7$ \\
Accuracy (\%) & 97.7 & $91.0-100.0$ \\
Likelihood ratio positive /LR (+) & $\sim$ & $\sim$ \\
Likelihood ratio negative/LR(-) & 0.03 & $0.01-0.1$ \\
\hline
\end{tabular}

\section{DISCUSSION}

Asymptomatic proteinuria is a sign of the beginning of diabetic nephropathy, occurs intermittently for several years and finally settled with massive proteinuria. In the beginning stages, mild proteinuria of diabetic nephropathy is difficult to distinguish with proteinuria due to membranous glomerulonephritis because of other reasons. Proteinuria is an indicator of diabetic nephropathy, but other causes must be ruled out such as congestive heart failure, pyelonephritis including physiological state and orthostatic. ${ }^{10}$ The TPCR is a quotient between urinary protein and urinary creatinine in units of $\mathrm{mg} / \mathrm{g}$ creatinine. This ratio is developed in order to reduce the problem of variability volume and urine concentration, and it reflects renal excretory function and creatinine levels are relatively stable, although the number of urine excreted low or high. ${ }^{12}$

Sensitivity TPCR to diagnose diabetic nephropathy is $97.4 \%$. It means that this test has ability to detect $97.4 \%$ out of patient suffer from diabetic nephropathy. The test is able to detect all of non diabetic nephropathy since it has specifity of $100 \%$. The PPV of $100 \%$ means that the probability of a person truely suffer from diabetic nephropathy is $100 \%$ when TPCR level is equal or more than $150 \mathrm{mg} / \mathrm{g}$. The NPV is $81.8 \%$ means that the probability of a person realy not suffer from diabetic nephropathy is $81.1 \%$ whenever value of TPCR is less than $150 \mathrm{mg} / \mathrm{g}$. The study gives result where the specificity is higher than sensitivity so that this TPCR test is better use to rule in diabetic nephropathy among patients with type 2 DM. It is also supported the result of likelihood ratio since both likelihood ratio for test positive and negative are far from value of one. It will give rise to biger changes between pre and posttest probality.

The cut-off in this study was based on a recommendation of AACE/ACE 2015 which states the value of microalbuminuria set using TPCR value in the range of $150-500 \mathrm{mg} / \mathrm{g}$. It was also based on research by Hashemapour et al., ${ }^{11}$ using a cut-off of $150 \mathrm{mg} / \mathrm{g} .{ }^{8,11}$ Hashemapour et al., ${ }^{11}$ report that TPCR had sensitivity of $94.5 \%$ and a specificity of $78.2 \%$. Another study conducted in Japan by Yamamoto et al., ${ }^{13}$ which involved 1,033 outpatients to detect microalbuminuria with TPCR using $150 \mathrm{mg} / \mathrm{g}$ as the cut-off. They reported that TPCR has sensitivity of $94.4 \%$ and specificity of $86.1 \%$ to diagnose diabetic nephropathy. ${ }^{13}$ The difference with this study was that they recruited the larger number of subject and conducted in a population of patients with cardiovascular risk factors.

Atkins et al. ${ }^{14}$ conducted a research to investigate sensitivity and specificity of TPCR to diagnose diabetic nephropathy. There were 
10,596 subjects recruited and the average age was more than 40 years old. The result of the study showed that TPCR had sensitivity and specificity of $91.7 \%$ and $95.3 \%$ at a cutoff of $0.20 \mathrm{mg} / \mathrm{mg}$. The study differed from our study because they used more sample size, different cut-off and used timed urine samples. ${ }^{14}$ Yadav et al., ${ }^{15}$ conducted a similar research in Nephal that involved 144 subjects where TPCR test was compared with AER as reference standard. They found that TPCR test had sensitivity and specificity of $96.6 \%$ and $74.4 \%$ at a cut-off of $150 \mathrm{mg} / \mathrm{g} .{ }^{15}$

Bukhari et al., ${ }^{14}$ conducted a similar research in Faisalabad which involved 134 patients with type $2 \mathrm{DM}$ whose age more than 40 years old. They reported that TPCR with a cut-off of $150 \mathrm{mg} / \mathrm{g}$ had a sensitivity of $95.2 \%$ and a specificity of $76.5 \%$ as compared with urine protein 24 hours to diagnose diabetic nephropathy. This research was different from our study since they recruited bigger number of subject so that the bias can be minimized. The TPCR examination had shown be more practical, time-saving and more convenient for patients. ${ }^{16}$ In addition to the parameters proteinuria, there are some markers that can be used to rule out the diagnosis of diabetic nephropathy include: cystatin $\mathrm{C}$, urine transferrin and proteomics. Serum cystatin $\mathrm{C}$ is a marker of renal function better than serum creatinine concentration and significant predictor of the development of end-stage renal failure compared with GFR. Cystatin $\mathrm{C}$ is filtered almost completely reabsorbed in the proximal tubule, with almost no tubular secretion of cystatin-C. Thus, increase cystatin- $\mathrm{C}$ in urine, indicates renal tubular damage rather than just damage to the glomerulus. In addition, cystatin- $\mathrm{C}$ urine will increase with the high degree of albuminuria and achieve a higher level macroalbuminuria in patients with DM. ${ }^{17}$

\section{CONCLUSIONS}

Laboratory examination of TPCR at level of equal or more than $150 \mathrm{mg} / \mathrm{g}$, has sensitivity, specificity, positive predictive value, negative predictive value, and accuracy of $97.4 \%, 1000 . \%, 100.0 \%, 81.8 \%$, and $97.7 \%$, respectively to diagnose diabetic nephropathy in patients with type $2 \mathrm{DM}$. Therefore, it could be used as an alternative whenever laboratory examination of AER unlikely to be done.

\section{ACKNOWLEDGEMENTS}

We would like to thank all patients who participated in this study.

\section{REFFERENCES}

1. World Health Organization. Global report on diabetes. Geneva: World Health Organiztion, 2016.

2. Wild S, Roglic G, Green A, Sicree R, King H. Global prevalence of diabetes: estimates for the year 2000 and projections for 2030 . Diabetes Care 2004; 27(5):1047-53. http:// dx.doi.org/10.2337/diacare.27.5.1047

3. Gross JL, de Azevedo MJ, Silveiro SP, Canani LH, Caramori ML, Zelmanovitz T. Diabetic nephropathy: diagnosis, prevention, and treatment. Diabetes Care 2005; 28(1):164-76. http://dx.doi.org/10.2337/diacare.28.1.164

4. Tuttle K. The evaluation of diabetic nephropathy. Adv Stud Med 2005; 5(1A):207.

5. Nichols GA, Vupputuri S, Lau H. Medical care costs associated with progression of diabetic nephropathy. Diabetes Care 2011; 34(11):2374-8. http://dx.doi.org/10.2337/ dc11-0475

6. Kataoka-Yahiro MR, Wong KA, Tamashiro J, Page V, Ching J, Li D. Evaluation of the national kidney foundation of Hawai'i's kidney early detection screening program. 
Hawaii J Med Public Health 2012; 71(7):18692.

7. Chadban S, Howell M, Twigg S, Thomas M, Jerums G, Cass A, et al. The CARl guideline. Assessment of kidney function in type 2 diabetes. Nephrology 2010; 15(Suppl 1):146-61. http://dx.doi.org/10.1111/j.14401797.2010.01239.x

8. Handelsman Y, Bloomgarden ZT, Grunberger G, Umpierrez G, Zimmerman RS, Bailey TS, et al. American Association of Clinical Endocrinologists and American College of Endocrinology--Clinical practice guidelines for developing a diabetes mellitus comprehensive care plan--2015--executive summary. Endocr Pract 2015; 21(4):413-37. http://dx.doi.org/10.4158/EP15672.GL

9. Methven S, MacGregor MS, Traynor JP, O'Reilly DS, Deighan CJ. Assessing proteinuria in chronic kidney disease: proteincreatinine ratio versus albumin-creatinine ratio. Nephrol Dial Transplalnt 2010; 25(9):2991-6. http://dx.doi.org/10.1093/ ndt/ gfq140

10. Price CP, Newall RG, Boyd JC. Use of protein: creatinine ratio measurements on random urine samples for prediction of significant proteinuria: a systematic review. Clin Chem 2005; 51(9):1577-86. http:// dx.doi.org/10.1373/clinchem.2005.049742

11. Hashemipour S, Charkhchian M, Javadi A, Afaghi A, Hajiaghamohamadi AA, Bastani $\mathrm{A}$, et al. Urinary total protein as the predictor of albuminuria in diabetic patients. Int $\mathrm{J}$ Endocrinol Metab 2012; 10(3):523-6. http:// dx.doi.org/10.5812/ijem.4236
12. Montero N, Soler MJ, Pascual MJ, Barrios C, Márquez E, Rodríguez E, et al. Correlation between the protein/creatinine ratio in spot urine and 24-hour urine protein. Nefrologia 2012; 32(4):494-501. http://dx.doi. org/10.3265/Nefrologia.pre2012.Apr.11300

13. Yamamoto K, Yamamoto H, Yoshida K, Niwa $\mathrm{K}$, Nishi Y, Mizuno A, et al. The total urine protein-to-creatinine ratio can predict the presence of microalbuminuria. PLoS One 2014; 9(3):e91067. http://dx.doi.org/10.1371/ journal.pone.0091067

14. Atkins RC, Briganti EM, Zimmet PZ, Chadban SJ. Association between albuminuria and proteinuria in the general population: the AusDiab study. Nephrol Dial Transplant 2003; 18(10):2170-4. http://dx.doi.org/10.1093/ndt/ gfg314

15. Yadav BK, Adhikari S, Gyawali P, Shrestha R, Poudel B, Khanal M. Use of protein: creatinine ratio in a random spot urine sample for predicting significant proteinuria in diabetes patient. Nepal Med Coll J 2010; 12(2):100-5.

16. Bukhari H, Shaukat A, Mahes A. Diabetic nephropathy; protein to creatinine ratio as a cost effective diagnostic. Prof Med J 2016; 23:302-6. http://dx.doi.org/10.17957/TPMJ/ 16.3184

17. Norberg M. Identifying risk of type 2 diabetes Epidemiologic perspectives from biomarkers to lifestyle [Dissertation]. Umeå: Umeå University, 2006. 